\title{
Bistand for bedre helse - Norges rolle
}

Den norske bistanden til helseformål er tredoblet siden tusenårsskiftet (1) - til totalt vel 3 milliarder kroner i 2008. Norge har satt av en milliard dollar over en tiårsperiode for å bedre helsetilstanden for mor og barn (2). Dette er viktige tiltak som bidrar til bedre barnehelse og som vi håper på sikt også vil gi bedre helse for mødre i utviklingsland. Et økende antall programmer mot enkeltsykdommer eller for spesielle målgrupper har imidlertid ført til økende fragmentering av innsatsen. For å motvirke dette ble det etter initiativ fra Norge og Storbritannia i 2007 etablert et nettverk av globale ledere (3) og et internasjonalt helsepartnerskap (IHP+) (4). Hensikten er å oppfylle de helserelaterte tusenårsmålene gjennom bedre koordinering av finansiering og implementering. Den siste rapporten fra 2009 om de helserelaterte tusenårsmålene som nettverket av ledere står bak inneholder mange gode forslag til nødvendige tiltak. Særlig legges det vekt på å redusere mødre-, neonatal- og barnedødeligheten gjennom sterkere og mer helhetlig satsing $(5$, s. 50-57).

Det var imidlertid overraskende at Norge valgte å gå inn for resultatbasert finansiering som viktig virkemiddel for å nå de helserelaterte tusenårsmålene og i 2007 bevilget 105 millioner dollar til Verdensbanken for dette formålet (6). Resultatbasert finansiering kan defineres som et system der overføring av penger eller andre materielle goder gjøres avhengig av i hvilken grad man oppnår forhåndsdefinerte resultater. Ifølge en litteraturgjennomgang fra Kunnskapssenteret mangler vi pålitelige data om effekten av dette finansieringssystemet i fattige land $(7,8)$. Det finnes eksempler på gunstige effekter på kort sikt, men Kunnskapssenterets gjennomgang viser at strategien kan stimulere til korrupsjon og gjøre at verdifulle tjenester som tiltakene ikke er rettet mot blir forsømt (8).

Andre måter å oppnå bedre helse og helsetjenester på, f.eks. en fornyet primærhelsetjenestestrategi basert på Alma Ata-visjonen fra 1978, synes tidligere ikke å ha vært prioritert av IPH+-gruppen (4). Denne strategien vektlegges sterkt av Verdens helseorganisasjon (9), og det er bra at nødvendigheten av en velfungerende primærhelsetjenese nå understrekes tydeligere også i 2009-rapporten om tusenårsmålene $(5$, s. 17).

Norges helsebistand har i de senere år endret karakter. Mesteparten av bistandsøkningen har kommet multilaterale og multi-/bilaterale programmer til gode. Mye av den bilaterale helsebistanden går nå til utvalgte land der det satses på smalere intervensjoner, med nokså liten vekt på institusjonelle partnerskap og langsiktig kompetansebygging. Den store satsingen fra norsk side på intervensjoner for å bedre helsetilstanden for mor og barn i India, Pakistan, Tanzania og Nigeria er eksempler på dette.

Det kan diskuteres om dette er en riktig strategi. Den bilaterale satsingen samsvarer ikke så godt med de overordnede målsettingene som ledernettverket og IPH+-gruppen skisserer. Den britiske økonomen Paul Collier anbefaler i boken De fattigste (10) at vi retter vår oppmerksomhet mot den fattigste milliarden som mest trenger internasjonalt samarbeid og bistand. Vi håper at 2009-rapporten om tusenårsmålene $(5, \mathrm{~s}$. 52$)$ kan tolkes som støtte til dette og som et signal om en gradvis omlegging av norsk helsebistand til en mer helhetlig satsing og begrenset til utvalgte land med de fattigste befolkningsgruppene. Ved hjelp av kunnskapsbasert innsats vil vi i slike områder raskt kunne oppnå betydelige effekter av bistanden i form av lavere sykelighet og dødelighet.

For å oppnå varige forbedringer kreves det tålmodig og langsiktig satsing på et helhetlig helsevesen. Dette bør kombineres med sterk vektlegging av tidkrevende, men nødvendige endringsprosesser på mange sektorer. Effektive tiltak for å redusere ødeleggende hjerneflukt av helsearbeidere og annet nøkkelpersonell fra fattige land må være en viktig del av strategien. Utdanningssektoren er spesielt viktig. Uten et godt utdannet lederskap nasjonalt, både i helsesektoren og på andre områder, vil lokalt baserte programmer og partnerskap vanskelig la seg realisere. I stedet for store reformer når man ofte lenger med kunnskapsbaserte, trinnvise endringer tilpasset lokale forhold. Når strategien for helsebistand skal viderutvikles, er det viktig at den blir basert på erfaringer og eksisterende kunnskap så vel som på ny kunnskap som kan genereres gjennom sterkere satsing på forskning for bedre implementering. På denne måten vil vi best sikre at bistanden fører til bedre helse og helsetjenester for de fattige, både på kort og på lang sikt.

\section{Gunnar Kvåle}

gunnar.kvale@cih.uib.no

Halvor Sommerfelt

halvor.sommerfelt@cih.uib.no

Gunnar Kvåle (f. 1942) er professor ved Senter for internasjonal helse, Universitetet i Bergen. Han er tidligere leder i Norsk forum for global helseforskning.

Halvor Sommerfelt (f. 1957) er professor ved Senter for internasjonal helse, Universitetet i Bergen, og overlege i bistilling ved Folkehelseinstituttet.

\section{Oppgitte interessekonflikter: Ingen}

\section{Litteratur}

1. Støre JG. Internasjonalt krafttak for mødre og barn. Vårt Land 15.9.2009. www.regjeringen.no/nb/dep/ud/dep/utenriksminister_jonas_gahr_store/ taler_artikler/2009/krafttak_moedre_barn.html?id=577112 (26.10.2009).

2. Statsministerens kontor. Global kampanje for å redusere barne- og mødredødelighet. www.regjeringen.no/nb/dep/smk/Aktuelle-temaer $5 /$ fnstusenarsmal/global-kampanje-for-a-redusere-barne--og.html?id=481756 (26.10.2009).

3. Network of Global Leaders. www.norad.no/en/Thematic+areas/ Health+and+aids/Maternal,+child+and+women's+health/The+Network+of+ Global+Leaders (28.10.2009).

4. International Health Partnership. www.internationalhealthpartnership.net/ ihp_plus_about_agencies_01.html (26.10.2009).

5. Leading by example - protecting the most vulnerable during economic crisis. The Global Campaign for the Health Millennium Development Goals, 2009. www.norad.no/en/Thematic+areas/Health+and+aids/Maternal,+child+ and+women's+health/Media+advisory (26.10.2009).

6. NORAD. Four countries suggested in the first round of the results-based financing initiative. www.norad.no/en/About+Norad/News+archive/129750.cms (26.10.2009)

7. Oxman AD, Fretheim A. Can paying for results help to achieve the Millennium Development Goals? Overview of the effectiveness of results-based financing. Journal of Evidence-Based Medicine 2009; 2: 70-83.

8. Oxman AD. Fretheim A. Can paying for results help to achieve the Millennium Development Goals? A critical review of selected evaluations of results-based financing. Journal of Evidence-Based Medicine 2009: 2: 184-95.

9. World Health Organization. World Health Report 2008. Primary health care now more than ever. Genève: WHO, 2008. www.who.int/whr/2008/en/index.html (26.10.2009).

10. Collier P. De fattigste. Veien ut av uføret. Oslo: Gyldendal, 2008. 